\title{
FLUXES OF ZOOPLANKTON BIOMASS BETWEEN A TIDAL ESTUARY AND THE SEA IN NORTHEASTERN BRAZIL
}

\author{
Mauro de Melo Júnior ${ }^{l, *}$; Maryse Nogueira Paranaguá ${ }^{2}$; Ralf Schwamborn ${ }^{3}$; \\ Sigrid Neumann Leitão ${ }^{l}$ and Werner Ekau ${ }^{4}$ \\ ${ }^{1}$ Departamento de Oceanografia da Universidade Federal de Pernambuco \\ (Av. da Arquitetura, s/n, 50670-901 Recife, PE, Brasil) \\ ${ }^{2}$ Departamento de Biologia da Universidade Federal Rural de Pernambuco \\ (Av. Dom Manuel de Medeiros, s/n., 52171-900 Recife, PE, Brasil) \\ ${ }^{3}$ Departamento de Zoologia da Universidade Federal de Pernambuco \\ (Av. Professor Moraes Rego, 235, 50740-550 Recife, PE, Brasil) \\ ${ }^{4}$ Center for Tropical Marine Ecology (ZMT, Bremen, Germany) \\ *corresponding author: m_melojunior@yahoo.com.br
}

\begin{abstract}
A B S TR ACT
The objective of this study was to quantify the zooplankton biomass transport between the Santa Cruz Channel (SCC) at Catuama north inlet and the adjacent shelf located in Itamaracá estuarine ecosystem, Pernambuco State, Northeastern Brazil. Sampling was carried out in August 2001 at spring and neap tides at three stations every 3-hour interval. Collections were made in three depths with a plankton pump coupled to a $300 \mu \mathrm{m}$ mesh size net. Current data were obtained with an ADCP (Acoustic Doppler Current Profiler). In laboratory, samples were filtered for wet weigh determination. High biomass variation was recorded, with highest values at nocturnal flood and ebb during spring tide. The average instantaneous biomass transport was $139.48 \pm 72.58 \mathrm{mg} \cdot \mathrm{m}^{-2} \mathrm{~s}^{-1}$, during spring tide and $36.63 \pm 27.66 \mathrm{mg} \cdot \mathrm{m}^{-2} \mathrm{~s}^{-1}$, during neap tide. No significant difference was registered between importation and exportation flows $(p>0.05)$, showing that the estuary both exports and imports high biomass during the rainy season. It can be concluded that the outwelling at SCC is high, however, differently from other places, importation is also high, probably due to the presence of reefs and patches of seagrass (Halodule wrightii) toward the shelf that create a distinct productive environment.
\end{abstract}

\section{RESUMO}

Este trabalho objetivou quantificar o transporte da biomassa zooplanctônica entre o Canal de Santa Cruz (CSC), na Barra de Catuama, e a plataforma adjacente no sistema estuarino de Itamaracá, Nordeste do Brasil. As coletas foram realizadas em agosto/2001 durante as marés de sizígia e quadratura em três estações a cada 3 horas. As coletas foram em três profundidades com auxílio de bomba acoplada à rede de plâncton com $300 \mu \mathrm{m}$ de abertura de malha. Dados de corrente foram obtidos com perfilador acústico de corrente (ADCP). Em laboratório, as amostras foram pesadas para obter o peso úmido. Foram registradas grandes variações na biomassa com valores mais altos nas marés enchente e vazante noturna durante maré de sizígia. O transporte instantâneo médio da biomassa foi de $139,48 \pm 72,58 \mathrm{mg} \cdot \mathrm{m}^{-2} \cdot \mathrm{s}^{-1}$, durante a sizígia, e de $36,63 \pm 27,66 \mathrm{mg} \cdot \mathrm{m}^{-2} \cdot \mathrm{s}^{-1}$, durante a quadratura. Os fluxos de importação e exportação não apresentaram diferenças significativas $(p>$ 0,05 ), evidenciando exportação e importação de grande quantidade de biomassa no período chuvoso. Conclui-se que a exportação do CSC é alta, porém diferentemente de outros locais, a importação também é alta, possivelmente pela presença de recifes e prados de fanerógamas (Halodule wrightii) em direção à plataforma, criando um ambiente produtivo distinto.

Descriptors: Estuarine-coastal fluxes, ADCP, Zooplankton biomass transport, High resolution 3-d transport model, Northeastern Brazil.

Descritores: Fluxos costa-estuário, ADCP, Transporte de biomassa zooplanctônica, Modelo de transporte em 3-D de alta resolução, Nordeste do Brasil. 


\section{INTRODUCTION}

Estuaries are highly dynamic transition areas between land and sea forming aquatic ecosystems that are characterized by intense environmental fluctuations. A variety of inter-related biotic and abiotic structural components and intensive chemical, physical and biological processes occurs in this ecosystems (DAY JR. et al., 1989; FLINDT et al., 1999; MCLUSKY and ELLIOT, 2004). Estuarine variabiliy is reflected in the dynamics of the biological populations, particularly planktonic ones (MARQUES et al., 2006).

For several reasons, plankton heterogeneity and community structure at a range of spatial and temporal scales is an important focus of ecological research. For example, zooplankton occupy an important ecological role in the transfer of energy from primary producers to higher trophic levels in estuarine areas (McLUSKY and ELLIOT, 2004; BELGRANO et al., 2005). Trophic levels can be expressed in terms of energy transfer; and, at each transfer, only a fraction of the energy is passed on and much is lost. The remainder is fixed as an increase in biomass, either through individual growth, or reproduction (LEVINTON, 1995). This means that zooplankton has a key role in biomass transfer. This biomass transfer is not limited to the estuarine food web, but also affects the adjacent marine food web through exportation (DAME and ALLEN, 1996; SCHWAMBORN, 1997; GIBSON, 2003).

The zooplankton biomass is quite often represented by a plankton volume measure. A practical, easy and quick way to measure biomass is the wet weight. This measure is obtained after removal of interstitial water and is used in productivity, nutritional and trophic web role studies (RÉ, 2000). However, in many zooplankton studies, this measure can supplement and complement, but do not substitute the numerical abundance and taxonomic composition (BEERS, 1981).

There is extensive information available about estuarine and marine zooplankton biomass in Northeastern Brazil (SCHWAMBORN, 1997; ESKINAZI-SANT'ANNA, 2000; PORTO NETO et al., 2000; SILVA et al., 2003; CUNHA, 2004; PEREIRA et al., 2005; SCHWAMBORN et al., 2007). However, little is known about the zooplankton biomass fluxes between tidal estuary and coastal area.

In Brazil, there is also a lack of research in this field. One of the few literature available is a paper about land-ocean fluxes of $\mathrm{C}, \mathrm{N}$ and $\mathrm{P}$ in Paranaguá Bay (Southern Brazil) by Marone et al. (2005) who concluded that Paranaguá Bay is a net heterotrophic system throughout the annual cycle, with higher net metabolic rates during the warm, rainy season.
The present study is the first one to present a quantitative approach about the zooplankton biomass tidal transport in a tropical ecosystem in Northeastern Brazil using the combination of high-resolution threedimensional ADCP current profiles and vertically and horizontally discrete plankton pumping techniques. An effort was made to assess the zooplankton biomass transport during the rainy season to test the outwelling hypothesis (ODUM, 1980) in Santa Cruz Channel system, Brazil, since an increase in river input occurs in that season resulting in higher land-ocean fluxes.

\section{Material and Methods}

Sampling was performed at Catuama Inlet (Northeastern Brazil), which separates the northern margin of Itamaracá Island from the adjacent continent (Fig. 1). Geographical locations of the sampling stations were provided by a GPS. Samples were taken during the rainy season on board a small vessel during spring tide (5 to 6 August, 2001) and neap tide (11 to 12 August, 2001), at 3-hour intervals, over $15 \mathrm{~h}$ for spring tide $(\mathrm{n}=32$ samples, obtained mainly during the night) and $24 \mathrm{~h}$ for neap tide ( $\mathrm{n}=56$ samples).

Plankton samples were taken with a pump at three stations along a transect across the inlet (Fig. 2). At the central station (Center), three depth levels were sampled $(50 \mathrm{~cm}$ below the surface, at midwater and 50 $\mathrm{cm}$ above the bottom), while at the continent and island stations, samples were taken only at subsurface and above the bottom. Water sample was pumped on board through a conical plankton net with $300 \mu \mathrm{m}$ mesh size for 3 to $5 \mathrm{~min}$. Approximately $100 \mathrm{~L}$ of water per $\mathrm{min}$ were filtered in each station. Immediately after sampling, all samples were fixed in $4 \%$ buffered formaldehyde in seawater according to OMORI and IKEDA (1984).

Before each sampling series, a complete 3-D current profile across the margins was obtained with an ADCP (Acoustic Doppler Current Profiler) probe fixed on a small vessel. Additionally, current velocity and direction were measured continuously with the ADCP (RD Instruments) during all plankton sampling stations.

Ten random current velocity data from ADCP were collected in each sampling station, as well as depth and time. From this an average velocity was obtained $\left(\mathrm{m} . \mathrm{s}^{-1}\right)$ to each sampled station and depth. In the laboratory, all samples were filtered onto preweighed glass-fiber filters (Whatman GFC) and measured at a balance, with a precision of $0.001 \mathrm{mg}$ for wet weight determination (NEWELL and NEWELL, 1963; BEERS, 1981; OMORI and IKEDA, 1984). Algae, mangrove and phanerogam fragments were removed from the samples before weighing. In the calculations of biomass, detritus and phytoplankton can influence wet weight 
measurements; however, we assumed that this unknown effect might not be significant. Zooplankton biomass was calculated by the formula: $B_{z}=P_{w} * V_{f}^{-1}$ (mg. $\mathrm{m}^{-3}$ ) where: $P_{w}=$ zooplankton wet weight. $V_{f}=$ total water volume filtered.

Biomass instantaneous transport rates $T i=$ $B o * V c m\left(\mathrm{mg} \cdot \mathrm{m}^{-2} \cdot \mathrm{s}^{-1}\right)$ of whole zooplankton were obtained for each sample by multiplying biomass $\left(\mathrm{mg} . \mathrm{m}^{-3}\right)$ by the current velocity $\left(\mathrm{m} \cdot \mathrm{s}^{-1}\right)$. Biomass instantaneous transport rates are shown in the Results covering all the samples taken in each depth for both spring and neap tides. Biomass total flow was calculated by: $F_{t}=B_{m} * Q\left(\mathrm{mg} \cdot \mathrm{s}^{-1}\right)$ where: $B_{m}=$ Average Zooplankton Biomass by serial sampling $\left(\mathrm{mg} \cdot \mathrm{m}^{-3}\right)$ and $Q=$ Total flow of liquid mass at sampling time $\left(\mathrm{m}^{-3} \cdot \mathrm{s}^{-1}\right)$.

A Mann-Whitney U-test (Zar, 1984) was used to determine whether there were significant differences in mean biomass between spring and neap tides, between day and night (only to neap tide), between sampling depths and between tides (high, ebb, low and flood). The relationships between biomass, tidal current and organism density were performed using Spearman correlation analysis.

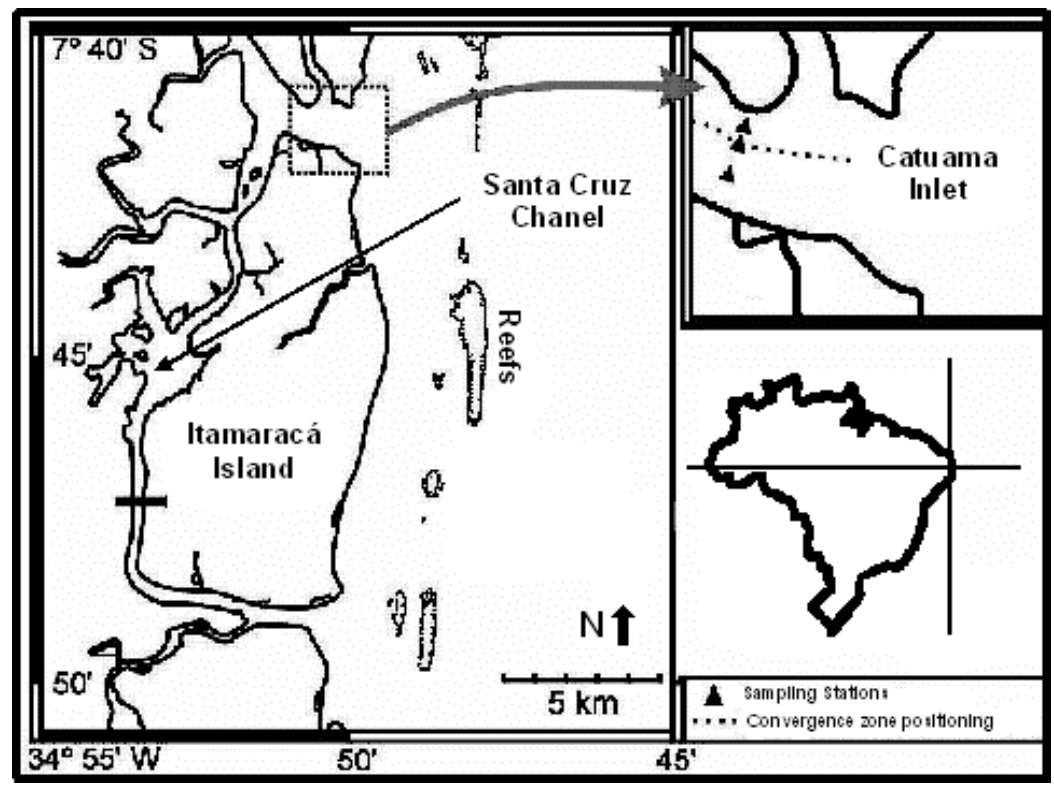

Fig. 1. Itamaracá Estuarine System (Pernambuco, Brazil), showing Catuama Inlet (Santa Cruz Chanel North mouth), with sampling stations in relation to convergence zone.

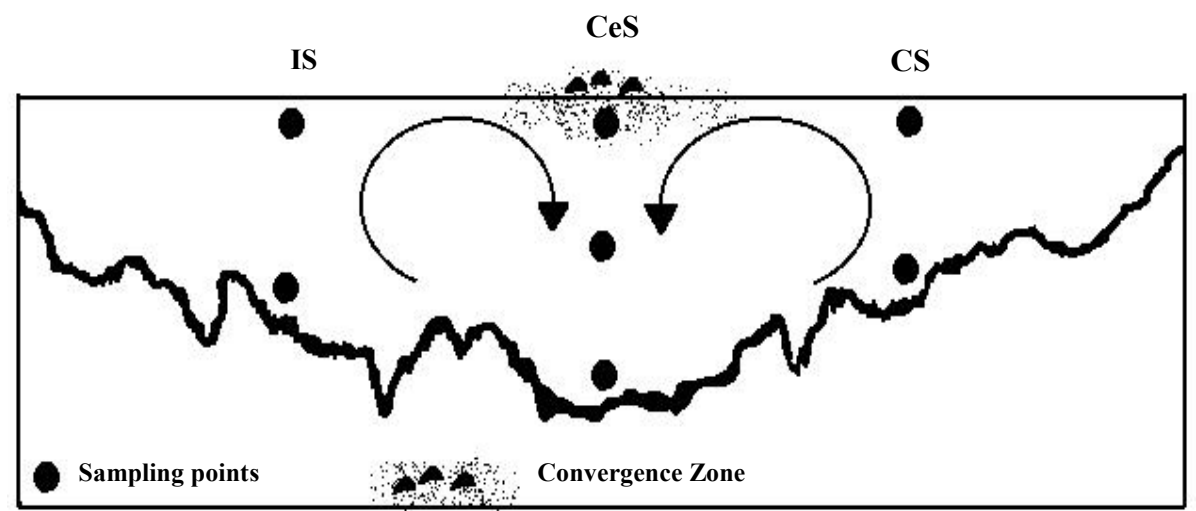

Fig. 2. Schematic profile in Catuama inlet, Santa Cruz Channel (Pernambuco, Brazil) in crosssection, with station and collection site indication. Arrows represent the estuarine convergence in Center Station. (IS, Island Station; CeS, Center Station; CS, Continental Station). 


\section{Results}

The ADCP profiles showed the predominance of vertically and horizontally heterogeneous current fields. Current velocity varied from 0.12 (flood) to $0.67 \mathrm{~m} . \mathrm{s}^{-1}$ (flood) during spring tide, and from 0.09 (flood) to $0.70 \mathrm{~m} \cdot \mathrm{s}^{-1}$ (ebb) during neap tide (Table 1). In general, higher values were observed in the surface layer during the ebb tide and in the bottom layer during the flood tide, as expected.

In the whole period, the zooplankton biomass varied from 13.46 to $800.00 \mathrm{mg} \cdot \mathrm{m}^{-3}$, both values registered during flood tide. During spring tide average zooplankton biomass was $355.46 \pm 195.21$ $\mathrm{mg} . \mathrm{m}^{-3}$, and at neap tide mean zooplankton biomass was $107.05 \pm 86.44 \mathrm{mg} \cdot \mathrm{m}^{-3}$. Accordingly to current velocity data in relation to the depht levels, zooplankton biomass was also not homogenous, with higher values mainly in the bottom layer. Mean values of $268.90 \pm 147.33 \mathrm{mg} \cdot \mathrm{m}^{-3}$ and $94.95 \pm 43.70 \mathrm{mg} \cdot \mathrm{m}^{-3}$ were found in the surface layer during spring and neap tides, respectively. On the other hand, in the bottom layer a mean value of $355.50 \pm 230.48 \mathrm{mg} \cdot \mathrm{m}^{-3}$ was registered during the spring tide and to the neap tide we found a mean of $149.66 \pm 127.47 \mathrm{mg} . \mathrm{m}^{-3}$. Even so, there was no significant difference between the layers. And the same was recorded for the horizontal profiles, where biomass values observed in the stations
(Continent, Island and Center) did not differ significantly.

The average instantaneous biomass transport was $139.48 \pm 72.58 \mathrm{mg} \cdot \mathrm{m}^{-2} \cdot \mathrm{s}^{-1}$, during spring tide and $36.63 \pm 27.66 \mathrm{mg} . \mathrm{m}^{-2} \cdot \mathrm{s}^{-1}$, during neap tide (Figs 3, 4). In general, higher mean values were found in the surface layer. During the spring tide, we registered mean values of $91.54 \pm 75.40 \mathrm{mg} \cdot \mathrm{m}^{-2} \cdot \mathrm{s}^{-1}$ and $88.01 \pm$ $62.13 \mathrm{mg} \cdot \mathrm{m}^{-2} . \mathrm{s}^{-1}$ in the surface and bottom layers, respectively. During the neap tide, we recorded a mean value of $33.47 \pm 24.19 \mathrm{mg} \cdot \mathrm{m}^{-2} . \mathrm{s}^{-1}$ to the surface layer and a mean of $28.70 \pm 29.58 \mathrm{mg} . \mathrm{m}^{-2} \cdot \mathrm{s}^{-1}$ to the bottom layer. As observed in relation to the biomass values, there was no significant difference between the vertical $(p>0.05)$ and horizontal profiles $(p>0.05)$. The main biomass transport peaks were related to peak densities of decapod larvae and calanoid copepods. The average instantaneous biomass transport was positively correlated with the average instantaneous total zooplankton transport $\left(\mathrm{r}_{\mathrm{s}}=0.8001\right)$ and with the planktonic decapods $\left(r_{\mathrm{s}}=0.7595\right)$.

The 24-hour biomass variation (neap tide) was more related to tidal level; however, day biomass differed significantly from night biomass $(\mathrm{p}=0.000)$, when higher values were registered, mainly during flood and ebb phases. Thus, most of the plankton biomass export and importation occurred during the night. On the other hand, there was no significant difference between the net balance importation versus exportation $(p>0.05)$.

Table 1. Average, minimum (min) and maximum (max) rates of current velocity $\left(\mathrm{m}^{-1} \mathrm{~s}^{-1}\right)$, zooplankton biomass $\left(\mathrm{mg} \cdot \mathrm{m}^{-3}\right)$ and instantaneous zooplankton biomass transport $\left(\mathrm{mg} \cdot \mathrm{m}^{-2} \cdot \mathrm{s}^{-1}\right)$ in Catuama Inlet (Northeastern Brazil), according to the balance of exportation versus importation, during spring (05 to 06 August, 2001) and neap (11 to 12 August, 2001) tides.

\begin{tabular}{|c|c|c|c|c|c|c|}
\hline & \multicolumn{3}{|c|}{ Exportation } & \multicolumn{3}{|c|}{ Importation } \\
\hline & average & $\min$ & $\max$ & average & $\min$ & $\max$ \\
\hline \multicolumn{7}{|l|}{ Spring tide } \\
\hline Current velocity & $0.32 \pm 0.15$ & 0.14 & 0.48 & $0.48 \pm 0.12$ & 0.12 & 0.67 \\
\hline Biomass & $405.75 \pm 131.19$ & 251.92 & 612.50 & $305.18 \pm 153.75$ & 13.46 & 800.00 \\
\hline Instantaneous transport & $141.22 \pm 95.65$ & 38.04 & 265.83 & $137.75 \pm 55.75$ & 1.99 & 229.32 \\
\hline \multicolumn{7}{|l|}{ Neap tide } \\
\hline Current velocity & $0.34 \pm 0.23$ & 0.10 & 0.70 & $0.23 \pm 0.10$ & 0.09 & 0.58 \\
\hline Biomass & $95.03 \pm 58.91$ & 21.05 & 217.31 & $139.08 \pm 80.37$ & 37.04 & 617.14 \\
\hline Instantaneous transport & $33.00 \pm 29.63$ & 3.52 & 91.50 & $40.27 \pm 21.32$ & 4.51 & 145.89 \\
\hline \multicolumn{7}{|l|}{ Total period (both tides) } \\
\hline Current velocity & $0.34 \pm 0.20$ & 0.10 & 0.70 & $0.39 \pm 0.15$ & 0.09 & 0.67 \\
\hline Biomass & $198.61 \pm 173.05$ & 21.05 & 612.50 & $212.16 \pm 142.93$ & 13.46 & 800.00 \\
\hline Instantaneous transport & $69.07 \pm 77.77$ & 3.52 & 265.83 & $83.16 \pm 63.03$ & 1.99 & 229.32 \\
\hline
\end{tabular}



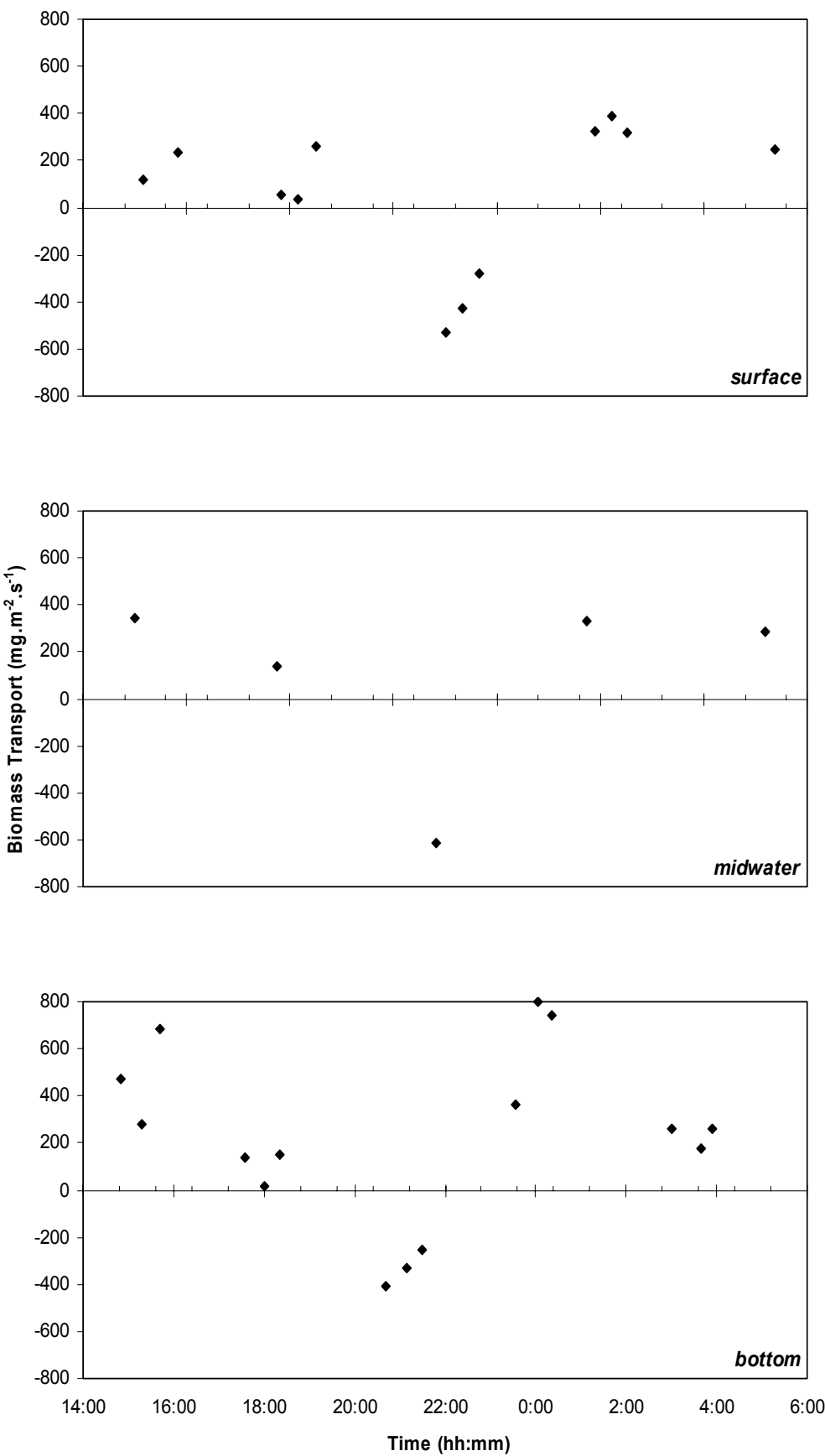

Fig. 3. Zooplankton biomass transport in Catuama Inlet (Northeastern Brazil), during spring tide (05 to 06 August, 2001), in three depth levels (surface, midwater and bottom). In each depth level the biomass transport rates are plotted according to its respective stations. Negative scores mean biomass export (ebb tides) from Catuama Inlet to coastal area. 

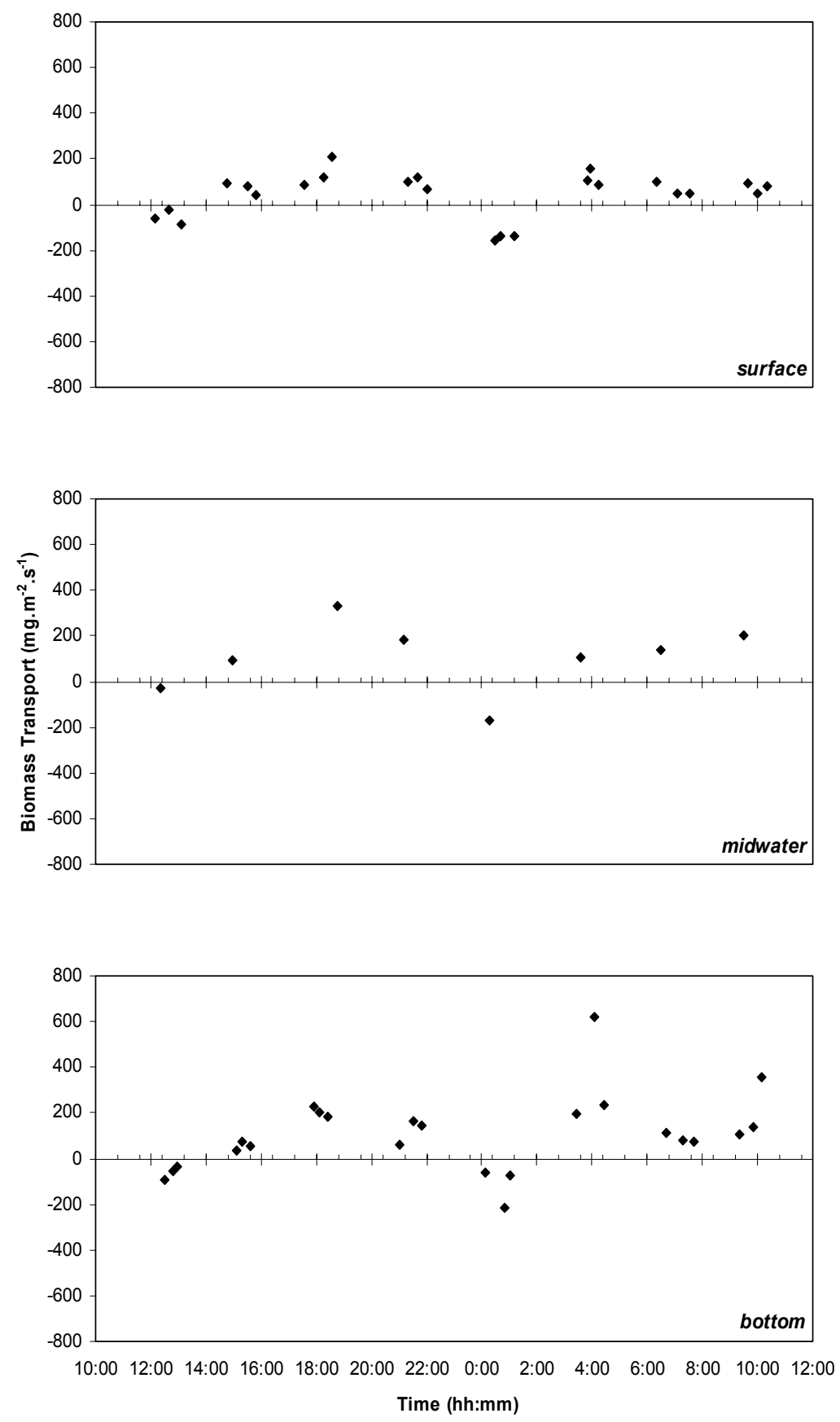

Fig. 4. Zooplankton biomass transport in Catuama Inlet (Northeastern Brazil), during neap tide (11 to 12 August, 2001), in three depth levels (surface, midwater and bottom). In each depth level the biomass transport rates are plotted according to its respective stations. Negative scores mean biomass export (ebb tides) from Catuama Inlet to coastal area. 
The zooplankton biomass flow presented significantly higher biomass transport rates during spring tide $(\mathrm{p}=0.000)$, with mean flows of $7.99 \times 10^{5}$ $\mathrm{mg} . \mathrm{s}^{-1}$ and a maximum of $14.6 \times 10^{5} \mathrm{mg} \cdot \mathrm{s}^{-1}$, during nocturnal ebb tide. Neap tide mean flow values were $1.26 \times 10^{5} \mathrm{mg} . \mathrm{s}^{-1}$ with a maximum of $2.29 \times 10^{5}$ mg.s $\mathrm{s}^{-1}$, also during nocturnal ebb tide (Fig. 5). There was significant difference between nocturnal and diurnal data $(\mathrm{p}=0.000)$.

\section{Discussion}

Catuama Inlet presented high variability in zooplankton biomass, with higher values when compared with other northeastern Brazil data (Table 2). For example, Silva et al. (2003) studying this same area found $47.4 \mathrm{mg} \cdot \mathrm{m}^{-3}$ (rainy season) and 57.9 mg. $\mathrm{m}^{-3}$ (dry season). Several studies show that seasonal periods can present marked differences in biomass data. Porto Neto et al. (2000), observed in
Tamandaré Bay (PE), an area under strong estuarine influence, higher biomass during the dry season (47.1 to $1239.3 \mathrm{mg} \cdot \mathrm{m}^{-3}$ ), and biomass variation occurring along the years. No seasonal trends were registered by Eskinazi-Sant'Anna (2000) in Pina Basin (50 km south of the studied area), although significant differences were registered by this author in a 24- hour scale.

Fernandes et al. (2002) found biomass values in Guanabara Bay (RJ), during the rainy summertime higher than those registered in Catuama Inlet. However, collections by those authors were carried out with a $200 \mu \mathrm{m}$ mesh size. Buskey (1993) found a higher contribution by microzooplankton (20$200 \mu \mathrm{m})$ than mesozooplankton $(>200 \mu \mathrm{m})$ to the total zooplankton biomass in a subtropical estuary. It is difficult to compare zooplankton biomass from study to study due to the different sampling methods and biomass estimation (PARK and MARSHALL, 2000).

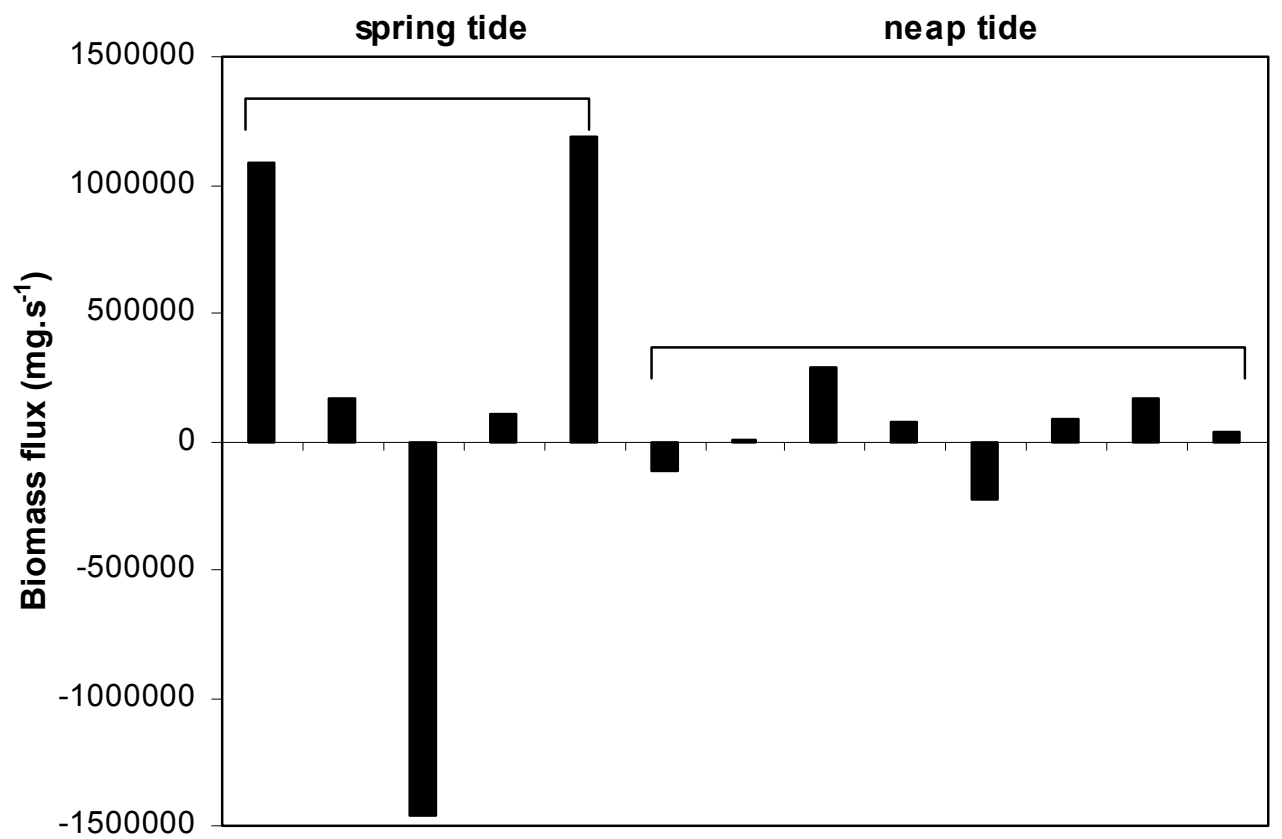

Fig. 5. Zooplankton biomass flow in Catuama Inlet (Northeastern Brazil), during spring (05 to 06 August, 2001 ) and neap (11 to 12 August, 2001) tides. Negative scores mean biomass export (ebb tides) from Catuama Inlet to coastal area. 
Table 2. Average, minimum and maximum zooplankton wet biomass $(>300 \mu \mathrm{m})$, in $\mathrm{mg} \cdot \mathrm{m}^{-3}$, from some coastal and estuarine ecosystems in Northeastern Brazil.

\begin{tabular}{|c|c|c|c|c|c|}
\hline \multirow[t]{2}{*}{ Area } & \multicolumn{3}{|c|}{ Wet biomass (mg.m ${ }^{-3}$ ) } & \multirow[t]{2}{*}{ Month/year } & \multirow[t]{2}{*}{ Reference } \\
\hline & average & minimum & maximum & & \\
\hline CS-NE, from PE to CE & 63.0 & 16.0 & 188.0 & Feb - Mar/1995 & Schwamborn (1997) \\
\hline \multirow[t]{2}{*}{ Itamaracá Island and ACS, PE } & 205.0 & 2.0 & 1262.0 & Feb - Mar /1995 & \\
\hline & & & & Mar - May/1996 & \\
\hline & 47.4 & 1.4 & 375.7 & Jul/1996 & Silva et al. (2003) \\
\hline Santa Cruz Channel, PE & 57.9 & 0.9 & 408.2 & Dec/1996 & \\
\hline Catuama Inlet, PE* & 384.5 & 56.4 & 2408.3 & Ago/2001 & Cunha (2004) \\
\hline Catuama Inlet, PE & 197.6 & 13.4 & 800.0 & Ago/2001 & Present paper \\
\hline Suape Bay, PE & --- & 44.0 & 3638.0 & Nov - Dec/1997 & Silva et al. (2004) \\
\hline & & & & Apr - May/1998 & \\
\hline Tamandaré Bay, PE & 24.39 & 9.2 & 73.9 & Jul/1989 - May/1990 & Porto Neto et al. (2000) \\
\hline & 336.51 & 47.1 & 1239.3 & Jan $/ 1998$ & \\
\hline & 92.31 & 27.7 & 266.5 & Jun/1998 & \\
\hline
\end{tabular}

CS: Continental Shelf; ACS: Adjacent Continental Shelf. (*) Sampling carried out simultaneously as the present paper, as subsurface hauls with a plankton net $300 \mu \mathrm{m}$ mesh size. NE: Northeastern Brazil, PE: Pernambuco State, CE: Ceará State.

The pump system was employed in the present research to permit more accurate specific depth and filtration sampling in situ as suggested by Powlik et al. (1991). Sampling methodology can influence the biomass data when comparing different measurements. Simultaneous subsurface plankton hauls carried out during the present study with the same mesh size net presented higher values than those obtained with the pump with a difference of 186.9 mg. $\mathrm{m}^{-3}$ between total mean (CUNHA, 2004). Net data are overestimated because the filtered volume does not correspond to the real one, as these samplers are under the clogging effect during hauls. The clogging effect varies according to the environmental condition (seston presence) and the way the net is operated, and the clogging is negligible in most applications of pumps when compared with nets (TAGGART and LEGGET, 1984; PINTO-COELHO, 2004). On the other hand, pumps have the disadvantage of damaging the collected organisms (BEERS, 1981), which does not contribute to increasing the biomass. We lessened the destruction of organisms, by reducing the tension in the catchment net. However, the data could be underestimated due to organism selectivity related to the tube diameter (PINTO-COELHO, 2004); in relation to the small rate of sampling (volume per unit time) we used the pump in an estuarine area where zooplankton densities are high as recommended by Harris et al. (1986). The escape potential of the organisms is a common criticism in using pumps, and copepods, per example, have a spectacular escape behavior (SINGARAJAH, 1969). Juvenile fish and large zooplankters possess a comparatively greater ability to evade sampling gear than smaller zooplankters considering their relative size and swiming ability (POWLIK et al., 1991). However, larger zooplankters remain difficult to capture with either pump or net samplers, with both methods subjected to sub-optimal performance (HARRIS et al., 1986; POWLIK et al., 1991). In our study, we considered the biomass sampling satisfactory.

Some biomass samples from Catuama Inlet included high quantities of suspended material as grass and algae fragments, sediments, detritus, hydrozoans, among others that were not completely removed from samples, only the bigger pieces. Most seston suspended in the water column, a common characteristic in estuarine systems, is important in biomass studies and can be considered a good estimative of the energy stored (RÉ, 2000; PINTOCOELHO, 2004). 
Variations in biomass at each location during different tidal cycles could reflect the changes in environmental parameters. Vertical profiles of salinity and temperature during the studied period (MELO JÚNIOR, 2005) indicate that the SCC acts as an arm of the coastal waters with limited exchange of fresh water, as already shown by Medeiros et al. (2001). Hence, most of the environmental parameters showed very little variation with changes in tides. Probably the coastal water moves up and down along the course of SCC with a limited water outflow during the ebb tide that is enriched with nutrients and organic matter derived from mangrove swarms, grass meadows and land activities, increasing biomass due to aggregations of vegetal fragments and, consequently, a great amount of biomass is exported. On the other hand, during flood tide a high load of relatively fine sediments and organic debris derived from offshore source (seagrass and reef biota) are brought by tidal currents increasing the wet weight. One question posed to our study was: is this imported biomass higher than the exported one? We wanted to test whether the Santa Cruz Estuary acts as source or sink for carbon during the rainy season. The function of mangrove as either a source or sink of organic matter and nutrients depends on the net flux of materials across the boundary estuary-coastal water. This boundary is somewhat undefined since estuarine water can extend to the continental shelf during periods of high freshwater discharge. Thus the coupling of mangroves to estuarine and coastal waters involves exchange across the mangrove-estuary boundary, followed by transport from the estuary to coastal waters (TWILLEY, 1988).

The classical outwelling hypothesis (ODUM, 1980) states that small coastal embayments (e.g. estuaries, wetlands) export their excess production to inshore marine waters. Actual measurements of 'outwelling' from coastal wetlands have yielded equivocal results (e.g. NIXON, 1980), with the magnitude, direction and form of organic matter exchange strongly dependent on factors such as the ratio of vegetated to open water areas (DAME et al., 1986; DAME and LEFEUVRE, 1994), the geomorphology of the wetlands (ODUM et al., 1979), the tidal regime (LEE 1990, 1995), the activities of macrofauna such as crabs (ROBERTSON, 1986; LEE, 1989, 1997), and general hydrodynamics of the system (DAME et al., 1986; WOLANSKI, 1995). In general, however, tropical mangrove ecosystems are expected to be net exporters, although the magnitude as well as spatial extent of export appears to be more limited than previously assumed (LEE, 1995, 2000).

In our study, no significant difference $(\mathrm{p}<$ 0.05 ) was found between the net balance importation versus exportation. In general, the total zooplankton biomass is exported during ebb tide and imported during flood. During spring tide a slight exportation occurred, while importation was higher during neap tide. It can be concluded that the outwelling at SCC is high, however differently from other places, importation is also high, problably due the presence of arenite reefs and patches of seagrass (Halodule wrightii) toward the shelf that create a distinct environment (SCHWAMBORN, 1997). Beyond the reefs, calcareous green algae (Halimeda sp) are abundant, originating a calcareous gravel bottom (KEMPF et al., 1967). Thus, during the rainy season the coastal area with a rich reef biota and seagrass meadow plays an important role in the SCC food web.

In spring tide, biomass values are threefold those of the neap tide mainly during flood and ebb tides and the most abundant groups are Calanoida copepods, Brachyura and Sergestoidea larvae (MELO JÚNIOR, 2005). Brachyura and Sergestoidea larvae have been related to high biomass values due to their body size and high density during some times of the year (ESKINAZI-SANT'ANNA;TUNDISI, 1986; ESKINAZI-SANT'ANNA, 2000; SILVA et al., 2004). At Pina Basin (PE), the meroplankton biomass was high, with Brachyura and other Decapoda larvae, important in the energy transfer dynamics of the system (ESKINAZI-SANT'ANNA, 2000).

The Catuama Inlet is a real corridor of zooplankton biomass exchange between SCC and the adjacent coastal area. In relation to tide phases the area was characterized by strong changes in biomass fluxes. This variability is related to the vertical migration in synchrony with the photoperiod and tidal cycle (SCHWAMBORN et al., 2007). Most species and stages showed characteristic vertical migration patterns in phase with tidal and diurnal cycles, enhancing retention or export from the estuary. In general, the results showed a greater biomass at night than during the day. The major reason for the more pronounced increase in biomass at night was the addition of Decapoda larvae, besides other taxa (mysids) (MELO JÚNIOR, 2005), which were not abundant numerically, but made a large contribution to biomass. Consequently, it is possible that during highest biomass importation/exportation, an increase in biological diversity in the area also occurs, mainly in the coastal area adjacent to Catuama Inlet, not only from species brought by the estuarine plume of SCC, but also by a myriad of organisms attracted by this rich energy source.

Our study showed that the combination of high-resolution three-dimensional ADCP current profiles with vertically and horizontally discrete plankton pumping techniques could help us to investigate exportation versus importation transport patterns of invertebrates in estuarine areas. 


\section{AcKNOWLEDGEMENTS}

We would like to thank the Conselho Nacional de Desenvolvimento Científico e Tecnológico (CNPq), for the financial support given for this study, as well as the research team members for their assistance on the fieldwork. The first author also wishes to thank the Coordenação de Aperfeiçoamento de Pessoal de Nível Superior (CAPES), for his M.Sc. fellowship. We are also grateful for the important suggestions given by the three anonimous referees and by Daniela Rimoldi Cunha (IO/USP).

\section{REFERENCES}

BEERS, J. R. Determinación de la biomassa del zooplancton. In: BOLTOVSKOY, D. (Ed.). Atlas del zooplancton del Atlantico Sudoccidental y métodos de trabajo con el zooplancton marino. Mar del Plata: INIDEP, 1981. p. 133-141.

BELGRANO, A.; SCHARLER, U.; DUNNE, J. ULANOWICS, R.E. Aquatic food webs, an ecosystem approach. Oxford , UK: Oxford University Press, 2005. $262 \mathrm{p}$.

BUSKEY, E. J. Annual pattern of micro- and mesozooplankton abundance and biomass in a subtropical estuary. J. Plankt.. Res., v. 15, n. 8, p. $907-$ 924, 1993.

CUNHA, A. G. Dinâmica temporal e transporte das larvas de Crustacea Decapoda na desembocadura norte do Canal de Santa Cruz - Itamaracá - Pernambuco, Brasil. Recife: Universidade Federal de Pernambuco, 2004. 65 p. (Monograph).

DAME, R.; ALLEN, D. Between estuaries and the sea. J. expl. mar. Biol. Ecol., v. 200, p. 169-185, 1996.

DAME, R.; LEFEUVRE, J.C. Tidal exchange: import-export of nutrients and organic matter in new and old world salt marshes: conclusions. In: MITSCH W.J. (Ed). Global wetlands: old world and new. Amsterdam: Elsevier Science, 1994. p. 303-305.

DAME, R.; CHRZANOWSKI, T.; BILDSTEIN, K.; KJERFVE, B.; MCKELLAR, H.; NELSON, D.; SPURRIER, J.; STANCYK, S.; STEVENSON, H.; VERNBERG, J.; ZINGMARK, R. The outwelling hypothesis and North Inlet, South Carolina. Mar. Ecol. Prog. Ser., v. 33, p. 217-229, 1986.

DAY JR., J. W.; HALL, C. A. J.; KEMP, W. M.; YÁÑEZARANCIBIA, A. Estuarine Ecology. New York: Willey-Interscience, $1989.556 \mathrm{p}$.

ESKINAZI-SANT'ANNA, E. M. Zooplankton abundance and biomass in a tropical estuary (Pina Estuary Northeast Brazil). Trabhs Oceanogr., Univ. Fed. Pernambuco, v. 28, n. 1, p. 21-34, 2000.

ESKINAZI-SANT'ANNA, E. M.; TUNDISI， J. G. Zooplâncton do estuário do Pina (Recife-PernambucoBrasil): composição e distribuição temporal. Rev. bras.. Oceanogr., v. 44, n. 1, p. 23-33, 1996.
FERNANDES, L. D. DE A.; BONECKER, S. L. C.; VALENTIM, J. L. 2002. Dynamic of decapod crustacean larvae on the entrance of Guanabara Bay. Braz. Arch. Biol. Technol., v. 45, n. 4, p. 491-498, 1996.

FLINDT, M. R.; PARDAL, M. A.; LILLEBO, A. I.; MARTINS I.; MARQUES J. C. Nutrient cycling and plant dynamics in estuaries: a brief review. Acta Oecol. int. J. Ecol., v. 20, n. 4, p. 237-248, 1999.

GIBSON, R. Go with the flow: tidal migration in marine animals. Hydrobiologia, v. 503153-162, 2003.

HARRIS, R. P.; FORTIER, I.; YOUNG, R. K. A large volume pump system for studies of the vertical distribution of fish larvae under open sea conditions. J. mar. biol. Ass. U.K., v. 66, p. 845-854, 1986.

KEMPF, M.; COUTINHO, P. N.; MORAIS, J. O. Plataforma continental do norte e nordeste do Brasil. Nota preliminar sobre a natureza do fundo. Trabhs Oceanogr., Univ. Fed. Pernambuco, v. 9/11, p. 9-26, 1967.

LEE, S.Y. Litter production and turnover of the mangrove Kandelia candel (L.) Druce in a Hong Kong tidal pond. Estuar. coast. Shelf Sci., v. 29, p. 75-87, 1989.

LEE, S.Y. Primary productivity and particulate organic matter flow in an estuarine mangrove-wetland in Hong Kong. Mar. Biol., v. 106, p. 453-463, 1990. .

LEE, S. Y. Mangrove outwelling: a review. Hydrobiologia, 295:203-212, 1995.

LEE, S.Y. Potential trophic importance of the faecal material of the mangrove sesarmine crab Sesarma messa. Mar. Ecol.Prog. Ser., v. 159, p. 275-284, 1997.

LEE, S.Y. Carbon dynamics of Deep Bay, eastern Pearl River estuary, China. II: Trophic relationship based on carbonand nitrogen- stable isotopes. Mar. Ecol. Prog. Ser., v. 205, p. 1-10, 2000.

LEVINTON, J.S. Marine Biology: function, biodiversity, ecology. New York: Oxford University Press., 1995. $420 \mathrm{p}$.

MARONE, E.; MACHADO, E. C. LOPES, R. M.; SILVA, E. T. Land-ocean fluxes in the Paranaguá Bay estuarine system, Southern Brazil. Braz. J. Oceanogr., v. 53, n. 3/4, p. 169-181, 2005.

MARQUES, S.C.; AZEITEIRO, U.M.; MARQUES, J.C.; MIGUEL NETO, J.; PARDAL, M.A. Zooplankton and ichthyoplankton communities in a temperate estuary: spatial and temporal patterns. J. Plankt. Res., v. 28, n. 3, p. 297-312, 2006.

MCLUSKY, D.S.; ELLIOTT, M. The estuarine ecosystem: ecology, threats and management. $3^{\text {rd }}$ ed. New York: Oxford University Press, 2004. 214 p.

MEDEIROS, C.; KJERFVE, B.; ARAÚJO FILHO, M.; NEUMANN-LEITÃO, S. The Itamaracá Estuarine Ecosystem, Brazil. In: U. SEELINGER; B. KJERFVE. (Org.). Ecological studies: coastal marine ecosystems of Latin America. New York: Springer-Verlag, 2001, v. 144 , p. $71-81$.

MELO JÚNIOR, M. DE. Padrões dinâmicos de transporte e migração do zooplâncton, com ênfase nos Decapoda planctônicos, na Barra de Catuama, Pernambuco Brasil. Recife: Universidade Federal de Pernambuco. 2005. 123 p. (M.Sc. Dissertation). (disponível em http://www.bdtd.ufpe.br/tedeSimplificado/tde_busca/arq uivo.php?codArquivo=1387).

NEWELL, G.; NEWELL, R. Marine plankton a pratical guide. London: H. Educat., 1963. 221 p. 
NIXON, S. W. Between coastal marshes and coastal waters a review of twenty years of speculation and research on the role of salt marshes in estuarine productivity and water chemistry. In: HAMILTON, P., MACDONALD, K. B. (Ed.). Estuarine and wetland processes. New York: Plenum Press, 1980. p. 437-525.

ODUM, E.P. The status of three ecosystem-level hypotheses regarding salt marsh estuaries: tidal subsidy, outwelling and detritus-based food chains. In: KENNEDY, V. (Ed.) Estuarine perspectives. New York: Academic Press, 1980. p. 485-495.

ODUM, W. E.; FISHER, J. S.; PRICKAL, J. C. 1979. Factors controlling the flux of particulate organic carbon from wetlands. In: LIVINGSTON, R. J. (Ed.). Ecological processes in coastal and marine systems. New York: Plenum Press, 1980. p. 69-80.

OMORI, M.; IKEDA, T. Methods in marine zooplankton ecology. New York: Wiley, 1984. $331 \mathrm{p}$.

PARK, G. S.; MARSHALL, H. G. Estuarine relationships between zooplankton community structure and trophic gradients. J. Plankt. Res., v. 22, n. 1,p. 121-135.

PEREIRA, L. C. C.; JIMENEZ, J. A.; KOENING, M. L.; PORTO NETO, F. F.; MEDEIROS, C.; COSTA, R. M. Effect of coastline properties and wastewater on plankton composition and distribution in a stressed environment on the north coast of Olinda - PE (Brazil). Braz. Arch. Biol. Technol., v. 48, n. 6, p. 1013-1026, 2005.

PINTO-COELHO, R. M. Métodos de coleta, preservação, contagem e determinação de biomassa em zooplâncton de águas epicontinentais. In: BICUDO, C. E. M.; BICUDO, D. E. C. Amostragem em limnologia. São Paulo: RiMa, 2004. p. 149-166

PORTO NETO, F. F.; NEUMANN-LEITÃO, S. NASCIMENTO-VIEIRA, D. A.; SILVA, A. P.; SILVA, T. A.; MOURA, M. C. O. Zooplâncton recifal de Tamandaré - PE (Brasil) e a influência dos manguezais na sua biodiversidade e biomassa. In: Mangrove 2000. Sustentabilidade de Estuário e Manguezais: Desafios e Perspectivas. Recife. ( CD-ROM).

POWLIK, J. J.; ST. JOHN, M. A.; BLAKE, R. W. A retrospective of plankton pumping systems, with notes on the comparative efficiency of towed nets. J. Plankt. Res., v. 13, n. 5, p. 901-912, 1991.

RÉ, P. M. A. Biologia marinha. Lisboa: Universidade de Lisboa, 2000. 94 p.
ROBERTSON, A I. Leaf-burying crabs: their influence on energy flow and export from mixed mangrove forests (Rhizophora spp.) in northeastern Australia. J. Expl mar. Biol. Ecol., v. 102, p. 237-248, 1986.

SCHWAMBORN, R. Influence of mangroves on community structure and nutrition of macrozooplankton in Northeast Brazil. ZMT Contr., Bremen, n. 4, 1997. 78 p.

SCHWAMBORN, R.; MELO JÚNIOR, M.; NEUMANNLEITÃO, S.; EKAU. W.; PARANAGUÁ, M. N. Dynamic patterns of transport and migration of zooplankton at Catuama Inlet (Pernambuco, Brazil), with emphasis on the Decapoda. Investg. mar., v. 35, n. 2, 2007. In press.

SILVA, A. P.; NEUMANN-LEITÃO, S.; SCHWAMBORN, R.; GUSMÃO, L. M. O.; SILVA, T. A. Mesozooplankton of a impacted bay in North Eastern Brazil. Braz. Arch. Biol. Technol., v. 47, n. 3, p. 485493, 2004.

SILVA, T. A.; NEUMANN-LEITÃO, S.; SCHWAMBORN, R.; GUSMÃO, L. M. O.; NASCIMENTO-VIEIRA, D. A. Diel and seasonal changes in the macrozooplankton community of a tropical estuary in Northeastern Brazil. Rev. bras. Zool., v. 20, n. 3, p. 439-446, 2003.

SINGARAJAH, K. V. Escape reactions of zooplankton: the avoidance of a pursuing siphon tube. J. expl. mar. Biol. Ecol., v. 3, p. 171-178, 1969.

TAGGART, C. T.; LEGGETT, W. C.. Efficiency of largevolume plankton pumps, and evaluation of a design sutable for development from small boats. Can. J. Fish. aquat. Sci., v. 41, p. 1428-1435, 1984.

TWILLEY, R. R. Coupling of mangroves to the productivity of estuarine and coastal waters. In: B.O. JANSSON (Ed.). Coastal offshore Ecosystem Interactions. Berlin: Springer-Verlag, p. 155-180. 1988.

WOLANSKI, E. Transport of sediment in mangrove swamps. Hydrobiologia, v. 295, p. 31-42, 1995.

ZAR, J. H.. Biostatistical analysis. $2^{\text {nd }}$ ed. Englewood Cliffs, N. J.: Prentice Hall, 1984. 718 p.

(Manuscript received 09 June 2006; revised 15 March 2007; accepted 18 March 2007) 